\title{
The Salt (Science-Arts-Language-Technology) Comenius Project: Primary School Students' Views about Salt *
}

\author{
Ursula ONDRATSCHEK $^{* *} \quad$ Ali Günay BALIM ${ }^{* * *} \quad$ Suat TURKOGUZ ${ }^{* * * *}$
}

Received: 04 Novamber 2013

Accepted: 28 May 2014

\begin{abstract}
This study aimed to investigate students' views towards salt structure, properties and application areas. "The SALT Comenius Project" initiated activities in 2012. This project was conducted with 10 European countries including Turkey, Germany, Italy, Poland, Greece, Spain, Estonia, Austria, Romania, and Scotland. The aim of this project is to develop friendships between primary school students through science, art, language, technology, and culture and to increase students' attention towards salt in daily life. In the first project meeting, the project partners developed a semi-structured questionnaire to measure students' views about the structure and properties of salt. Participants were 161 primary school students from project partner countries. In this study, Data were gathered by the qualitative research method. In students' views, salt is a substance used in food; salt is gathered only from sea salt; salt is composed of tiny crystals; salt is bad for health; salt is gathered only from rocks.
\end{abstract}

Keywords: views toward salt, primary school students

\section{Introduction}

Salt is not only an important substance in human beings and other living organisms but also a unique chemical and mineral substance that holds an important role in the economy and development levels of countries. Salt is one of the main materials at every stages of living bodies and at all levels of countries' industry. Although the word Salt is used in very different meanings in chemistry, in everyday language it is named only as rock that can be eaten and is used for substances that are composed of sodium and chloride elements (Gölbaş \& Başıüyük, 2012). Salt is a substance that originates from acid-base reaction. Today, there are 14 thousand usage areas of salt ranging from pharmaceutical production, melting ice on the roads, and softening of water to soap production (Kurlansky, 2003). Salt, which has importance in terms of history of civilization, is a valuable mineral. With the development of the human being, the use of salt has been acknowledged and its importance has increased. This valuable mineral has gained social, religious and political identity in various parts of the world and has impacted the society. Salt was first used to enhance the flavor of food and to store them but in time it began to take a role in industry and in the last two centuries it has become a substance consumed in many areas including health (Avc1, 2003).

\footnotetext{
* This article was presented World Conference on New Trends in Science Education (WCNTSE-2013) in Krakow, Poland.

${ }^{* *}$ Salt Comenius Project Coordinator, Grundschule im Beerwinkel, Berlin, Germany, ullaon@penticom.de

**** Assoc. Prof. Dr., Dokuz Eylül University, İzmir, Turkey, agbalim@gmail.com

**** Corresponding Author: Assist. Prof. Dr., Dokuz Eylül University, İzmir, Turkey, suat.turkoguz@gmail.com
} 
Salt can be observed transparent in pure form but in the statements of structural disorders or impurity form it can be seen in the colours of grey, yellow, blue, green, orange and pink. Salt can be found naturally in oceans, lakes and rocks in the world. Salt is commonly used in nutrient, agriculture, medicine, traffic, industry and improvement of groundwater (DPT, 1995; ESPA, 2003; Gölbaş \& Başıüyük, 2012, Kostick, 2001). Consumption of salt is generally used in the food sector, the chemistry sector and melting ice. When salt is used to melt ice on the roads, it can cause damage to metal components in roads, road texture, underground water and vegetation.

It is well known that salt was used as a commercial tool directly or instead of money. The English word "salary" which means "earning money" comes from the Latin word "salarium". At the beginning, this word was used for the expression of salt appropriation given to Roman soldiers (Avc1, 2003). In the 16th century, richness was associated with salt in Europe. At this term, jewellery covered salt made from gold and silver was manufactured (Gölbaş \& Başıbüyük, 2012; Kurlansky, 2003). Today in some societies, salt is still accepted as a payment tool like other valuable metals (Bloch, 1996). In 17th and 18th centuries, taxes were put on salt and people started to provide and use salt illegally (Gölbaş \& Başıüyük, 2012). In the 17th century, salt tax caused significant problems. In the 18 th century 3000 people using salt illegally were executed (Kurlansky, 2003).

Salt is at the top of basic materials used in everyday food. People's daily need of salt is less than it is required and the amount of salt should be less than $500 \mathrm{mg}$. Salt creates a great risk to especially cardiac patients in terms of health (Van der Veen, De Graaf, Van Dis, \& Van Staveren, 1999). Lack of salt can lead to weakness and irritability in the short term and in the long term lack of salt causes the decrease in blood pressure and the ability to keep water in the body. This can bring coma and death in further stages. On the other hand, many research studies put forward that there is a relationship between high salt consumption and high-tension and cardiovascular diseases. The use of more or less salt is essential in terms of human health. The use of too much salt can be the reason for various problems (Avc1, 2003; Çom, Irmak, Kesici \& Ilgaz, 2011; Kurlansky, 2003).

There are numerous research studies on the information, attitude, perception and awareness on salt. Marakis, Tsigarida, Mila and Panagiotakos (2013) investigated the knowledge, attitude and behaviors of Greek people in accordance with sociodemographic variables in their study they conducted in Greece in 2013. In this study, they aimed at investigationg the blanks of Greek people in terms of high salt consumption. In the study, it was thought that a great majority of Greek people are not knowledgeable about the daily amount of salt to be consumed, that children should consume lesser amounts of salt, that sodium is an ingredient of salt and that salt is obtained generally from the nutrients in foods, bread and meat products. Moreover, it was also stressed out that the measurement tool that was used in the study should be used in prospective studies, as well. 
Webster, Li, Dunford, Nowson and Neal (2010) investigated the awareness and behaviors of Austrians regarding the consumption of salt. Test subjects from various age groups and different regions of Austria were involved in the study. The research was performed via online surveys. Whereas $32 \%$ of the participants stated that salt was unhealthy, $14 \%$ knew the upper limit of salt consumption. $70 \%$ were able to say that they could identify the diet salt from foods and $25 \%$ told that they checked the food labels for this information. It was understood from the results of the study that there is awareness in Austria of the fact that salt consumption at moderate levels has an effect on health. According to these results, this can be evincible in terms of reduction of salt consumption. The researchers emphasised that work devoted to the enhancement of awareness and attitude towards salt consumption should be performed.

With their research report performed in Austria in 2009, Grimes, Riddell and Nowson (2009) investigated the knowledge and attitudes of consumers regarding salt consumption and labeled information on salt. A survey measuring the knowledge and attitudes regarding salt was used. The study was carried out with 474 test subjects. $88 \%$ of the participants had knowledge on the relation between salt and blood pressure. $65 \%$ were unable to define the presence of sodium in salt properly. $69 \%$ stated that they checked the salt figures on the labels. $50 \%$ did not take note of the properties of the salt in labeled products. When consumers are informed on the fact that consumption of salt at high levels will be hazardous for health, an increase in the use of salt in foods and the use of food labels can occur. It was emphasised that in order to make the picking of the products with lower salt levels, significations like "health-friendly", "food that is good for health" should be used.

Sánchez et al. (2012) researched the perceptions, knowledge and attitudes of the people living in Argentina, Costa Rica and Ecuador regarding salt consumption. It was stated that those people who did not know the definition of salt did not have knowledge on what the sodium in salt is. In spite of the fact that there are socio-cultural differences, it was found out by some research performed in this country that salt is only a flavourer and, in other studies, a lack of knowledge regarding salt and sodium was encountered. It can be seen in these research studies that were carried out in different cultures the concept of salt is not wholly comprehended. The studies conducted in Austria had similar findings, too. Researchers were unable to demonstrate the source of salt in processed foods and convenience foods on food labels in their research. Salt concept do not understood on acoount of not having common terminology. Consequently, it can be defined new common terminology about salt concept.

According to an evaluation on the consumption of salt, if salt consumption in 23 European countries decreases by $15 \%$ in over a decade, a population of 8.5 million will be protected from death of chronic diseases (Asaria, Chisholm, Mathers, Ezzati \& Beaglehole, 2007). According to the 21 January 2010 issue of the Wall Street Journal, a nation-wide program devoted to the reduction of diet salt in the United States was commenced, following the tens of thousands of heart attacks and death of 24 million 
people. Just as the overuse of salt might be hazardous, consuming little salt can be harmful, as well. Besides heart attack, consuming salt in insufficient amounts might cause insüline resistance (Wang, 2010).

The concept of salt is generally only taught to elementary and high school students as a substance that can be made as a result of acid-base neutralization in Chemistry and it takes place in diffusion and osmosis in Biology. Today the use of much salt is tried to be emphasized in education with different views to encourage the correct use of salt and its importance because it creates health and environment issues. In her study Seçken (2010) determined students' misconceptions related to salt. She revealed the misconceptions about salt by asking open-ended questions and multiple choice tests using information from various chemistry textbooks. 121 undergraduate students participated in this research. Students expressed the salt concept as neutralization of acid and base and they couldn't give different examples about how salt is used in daily life except for food consumption. At the end of the study it has emerged that students know salt as $\mathrm{NaCl}$ but they are not aware of other metal salts. It is seen that she used the Lowry-Bronsted definition in determining which of the 15 compounds given to the students are salt and, thus, there was no confusion. When the samples given were determined according to the other identifications, the students suffered a conceptual confusion. To exemplify, the compounds Iron (III) Chloride and Chrome (III) Chloride are not salt identified according to the Lowry Bronsted definition. For this reason, the students had problems while deciding whether these compounds were salt or not. The students thought that salt only consists of acid-base reaction whereas salt may stem from metal-acid reactions, too. Students did not know salt other than sodium chloride, ammonium chloride and sodium acetate. Students should be introduced to different salt samples and experiments should be done (Seçken, 2010).

Below are several misconceptions of students regarding salt;

-Salt affects the melting speed of ice.

-Marine and rock salt is not better than table salt.

-Table salt is not pure; rock salt is pure. Table salt is not pure due to the fact that it goes through chemical processes.

-Salt leads to excessive sweating.

-Salt is present in all foods.

-Salt loses mass when added to water.

-Salt gasifies when added to water (Taber, 2002).

-Salt dissolves only when granulated into very small particules.

-Salt are not an ionic compound (Kibirige, Osodo \& Tlala, 2014).

The conceptual knowledge of salt is in a negative relationship with the age of individuals. It is evident that as the individuals get older, their knowledge related to salt decreases and the misconceptions increase. In relation with this, research findings show that as the misconceptions of salt increase, the taste perception of salt decreases (Sarmugam, Worsley \& Wang, 2013). 
Kurt, Ekici and Aksu (2013) put forward the mental models of biology teachers on the concept of salt. Following the researchers, it was determined that the mental models of teacher candidates concentrate on the chemical properties of salt and its use in daily life. Moreover, it was detected that biology teacher candidates have cognitive inadequacies on the concept of salt and many alternative notions in numerous categories.

There are other researches revealing salts' effects on human psychology. Parman (2002) examined the relationship between the amount of consumed salt in food and attitudes toward salt. In the study, she questioned the attitudes toward salt according to societies. As known, negative attitudes toward salt in all societies are seen because of its noticeable negative effects on health. As a result, an association was made between the attitudes toward salt and the amount of salt used in food diet and it revealed that the amount of consumed salt was associated with the culture of environment. The study also revealed that traditional attitudes were more effective on the daily use of salt.

Inasmuch as studies devoted to salt have been performed, it can be avowed that the number of the studies on salt is rather inadequate regarding educational implementations. The studies on salt are at large concentrated in the fields of medicine, health and engineering. There have also been recent studies that are orientated on psychological behaviors. Resulting from the fact that the concept of salt is the common topic of biology, physics and chemistry subjects, the determination of the misconceptions regarding salt is of prime importance. Literature searches reveal very few studies that are devoted to the concept of salt and the teaching of it. However, we can see that the studies on the concept of salt in the field of education are involved only in the concepts of acid, bases and neutralization. In Turkey, a course unit or title on the teaching of the concept of salt at high school or primary level is not seen. Only acids, bases and neutralization are dealt with in terms of chemical processes (Seçken, 2010). Although salt is very commonly used in daily life and there have been trends in the fields of medicine and engineering towards this concept, the lack of such tendencies in the field of education is felt. The success of campaigns devoted to the reduction of salt consumption can be maintained through raising awareness among the consumers on salt rather than action plans intended at reducing salt consumption (Marakis et al., 2013). Therefore, the concept of salt which is commonly used in daily life is an important matter in the sense of being an interdisciplinary topic.

The decline of salt today while it was a priceless substance throughout the history is not an indication for the importance of salt. Salt is an important topic for lessons to understand how tangible and spiritual values imposed to any substance were formed and changed in time (Gölbaş \& Başıüyük, 2012). In this context, several studies related to salt consumption in our country are conducted to prevent the occurrence of diseases and to protect the public health (Çom, Irmak, Kesici \& Ilgaz, 2011). With this European Union Comenius Project, it is aimed to reveal the behaviors of Turkish primary school students about salt, to compare them with primary school 
students studying in other European countries involved in the project and to give suggestions in terms of education.

\section{Method}

In the study, as factual and cultural circumstances were investigated profoundly, phenomenonology (the science of facts) pattern of the qualitative research patterns was utilized. In phenomenonology studies, the disclosure and interpretation of individual perceptions or perspectives regarding a fact is aimed (Yıldırım \& Şimşek, 2005). The cognitive and emotional perceptions of the students that participated in the study were aimed to be determined at a cultural level. Data in the study are collected with semistructured open ended questions from students studying at 10 European Countries involved in "The SALT (Science-Arts-Language-Technology) Comenius Project" and analyzed by examining the documents obtained from these questions. In a qualitative research method, the common opinions of individuals participated in the study are evaluated by forming themes and codes after examined within specific criteria (Geray, 2006; Yıldırım \& Şimşek, 2005). The measurement tool that was used is intended at measuring the students' a-knowledge of salt, b-awareness of salt in terms of areas of usage, c-knowledge of the recovery of salt and d-awareness of the salt types encountered in daily life. Herewith, these four sub headings of the measurement tool make up the dependent variables of the study. 10 participating countries represent the independent variables. The comparison of the dependent variables that are made up of these sub subject by country basis underlies the study.

\section{Participants}

The research was carried out with 161 primary school students studying at 6th, 7th and 8th grades from Turkey, Germany, Poland, Romania, Greece, Estonia, Spain, Italy, Austria and Scotland taking part in "The Salt (Science-Arts-LanguageTechnology)" Comenius Project. It was decided that the number of participants from different countries should be adjusted as at least 5 and at most 20 students from each country. Consensus on the fact that the students participating in the study were chosen among the most successful students of the participating elementary school and the voluntariness of the students was taken note of. Within this scope, as can be seen in Table 1 below, the male-female distribution in some countries differs. The age distribution of students equals to 8-12 age range. The country with the smallest number of participants is Austria. Table 1 below reveals the distribution of participants by countries. 
Table 1

The distribution of participants by countries and gender

\begin{tabular}{lllll}
\hline Country & Male (f) & Female (f) & Total (f) & Percentage (\%) \\
\hline Turkey (TR) & 8 & 7 & 15 & 8.8 \\
Greece (GR) & 10 & 10 & 20 & 11.8 \\
Germany (D) & 2 & 11 & 13 & 7.7 \\
Scotland (SCO) & 9 & 6 & 15 & 8.8 \\
Espaniol (E) & 10 & 10 & 20 & 11.8 \\
Poland (PL) & 10 & 10 & 20 & 11.8 \\
Romania (RO) & 9 & 11 & 20 & 11.8 \\
Estonia (EST) & 12 & 8 & 20 & 11.8 \\
Italy (I) & 8 & 12 & 20 & 11.8 \\
Austria (A) & 3 & 4 & 7 & 4.1 \\
Total & 81 & 89 & 170 & 100 \\
Percentage (\%) & 47.7 & 52.4 & 100 & \\
\hline
\end{tabular}

\section{Data Collection Tools}

Semi-structured form which includes five open ended questions was used as data collection tool. The coordinators from the European countries that participated in the project "The SALT Comenius", held 10 meetings on the dates specified in the project calendar, in a way that meetings were held once in each country and twice a year. In the initial meetings, the coordinators from each country were required to present the definitions of salt in their countries, the usage areas of salt, known production processes, examples of salt they encountered in their daily lives and the activities devoted to the concept of salt in their curriculums in accordance with the scope of the project. In line with the themes spawned by the presentations, each country coordinator was asked to produce questions about salt. The questions were projected and put to vote in turn and the most favorite questions were decided to be a survey form made up of open ended questions.

The extent to which the measurement tool represented the perceptions of the concept of salt was determined by the coordinators and project consultants from each country via receiving expert opinion; the questions prepared at the meeting were put to the vote and their structural, contextual and face validities were checked by the reinforcement of these views. Prior to the general survey, the survey form was practiced on 10 students in the country where the project coordinator was present; the answers by those 10 students and the unclear points were projected to discuss the functionality of the questions and revisions were made where needed. The survey form, prepared in English, was translated by the coordinators into their language and given to the students. 
Each coordinator formed codes and keys for each question and presented them in the common meeting. Following the meeting, an excel table containing the common codes and keys was made and the data obtained from the students by the coordinators and teachers from each country was distributed among the codes and themes in the excel table. The data was put together in an excel table and e-mailed to the project coordinator. After analyzing the data, the project coordinator presented the results at the general meeting that he organized and activities that were in compliance with the data received from the survey and the scope of the project were designed. This form consists of these five questions: " 1 .What is salt? Write down three things about salt you already know spontaneously. Leave it out, if you don't know anything, 2. What do we need salt for? Tick off the answers you think are right, 3 . Do you think salt is necessary for: Tick off Yes or No or don't know 4. Where do we find salt for production? Three ticks only! 5. What kind of salt have you already seen?".

After the provision of the structure, content and face validity of the measurement tool, the English survey form was practiced upon 10 students in Berlin, Germany where the project coordinator was present. The answers and the unclear points were asked and the project form was renovated in the general meeting to be given to the participating country coordinators in its new format. Once the participating country coordinators translated the form into their languages, the survey form was given to the students who were asked to fill them up in 20 minutes. The written forms taken from the students were examined by the coordinators and the answers given were assessed by teams of specialists. After the data was uploaded to the excel file, it was sent to the head of the project. Moreover, each form filled up by the students was scanned and e-mailed to the head of the project. The data were collected from students in Turkey, Germany, Poland, Romania, Greece, Estonia, Spain Italy, Austria and Scotland via asking them to fill in the form distributed as questionnaire.

\section{Data Analysis}

In data analysis, the "Content Analysis Technique" was used. The aim of content analysis is to reach common themes from data and to make relationship between them. In content analysis, common themes under common codes are collected from similar data and to understand them these codes are interpreted (Filbeck, 2002; Gokçe, 2006; Yildırım \& Simsek, 2005). In content analysis, to provide validity and reliability of data, ratio scales which measure or indicate the situations and control lists are designed. Analysis was made by two researchers and one field expert. Firstly the researchers created themes independently from each other. Then they compared these themes and determined common themes. Reliability of research was calculated by using the formula: Reliability= [Common opinions / (Common opinions + Different opinions)] x100 (Miles \& Huberman, 1994). According to this, the consistency of codes between three researchers was determined as $80 \%$. To increase these correspondence rates, experts and researchers came together, compared the forms and evaluated them by examining and discussing different situations and overlooked details again and again. In this way, the reliability of study and open-ended questions were provided. 


\section{Findings}

A survey of opinions which aims to determine students' views in 10 European countries included in project about salt and its usage areas and includes 5 open-ended items was distributed to students. The content analysis produced the following findings.

\section{Views of the Students on the Concept of Salt}

A survey of opinions which aims to determine students' views in 10 European countries included in project about salt and its usage areas and includes 5 open-ended items was distributed to students. The content analysis produced the following findings.

\section{Table 2}

The percentage distribution of the views of the students regarding the question "What is salt?"

\begin{tabular}{llllll}
\multicolumn{1}{c}{ Views } & Food & Structure & Health & Need & Total \\
Country & Definition & Definition & Definition & Areas & Views \\
\hline TR & $10(43.4 \%)$ & $5(21.7 \%)$ & $8(34.7 \%)$ & $0(0.0 \%)$ & 23 \\
GR & $4(36.3 \%)$ & $2(18.1 \%)$ & $3(27.2 \%)$ & $2(18.1 \%)$ & 11 \\
D & $5(33.3 \%)$ & $4(26.6 \%)$ & $3(20.0 \%)$ & $3(20.0 \%)$ & 15 \\
SCO & $15(44.1 \%)$ & $13(38.2 \%)$ & $2(5.8 \%)$ & $4(11.7 \%)$ & 34 \\
E & $16(44.4 \%)$ & $10(27.7 \%)$ & $8(22.2 \%)$ & $2(5.5 \%)$ & 36 \\
PL & $5(23.8 \%)$ & $13(61.9 \%)$ & $3(14.2 \%)$ & $0(0.0 \%)$ & 21 \\
RO & $17(51.5 \%)$ & $10(30.3 \%)$ & $1(3.0 \%)$ & $5(15.1 \%)$ & 33 \\
EST & $7(38.8 \%)$ & $5(27.7 \%)$ & $1(5.5 \%)$ & $5(27.7 \%)$ & 18 \\
I & $0(0.0 \%)$ & $5(45.4 \%)$ & $4(36.3 \%)$ & $2(18.1 \%)$ & 11 \\
A & $0(0.0 \%)$ & $6(100.0 \%)$ & $0(0.0 \%)$ & $0(0.0 \%)$ & 6 \\
Total & 79 & 73 & 33 & 23 & 208 \\
Percentage & $38.0 \%$ & $35.1 \%$ & $15.9 \%$ & $11.1 \%$ &
\end{tabular}

Definition related to food: -The salt used in cooking, -We put it on food, -Salt is a spice; ${ }^{2}$ Definition related to structure: -We find salt in oceans and seas, -Salt is made from small crystals and white, -It is a mineral, -Salt has different colours and forms, -Rock salt; ${ }^{3}$ Definition related to health: -Salt is good for beauty, -It is bad for your health, -Salt is in the body, -Salt makes you thristy; ${ }^{4}$ Definiton related to usage areas: -It melts the ice, -Salt is poison for snails and slugs, -Salt can kill plants

According to the results in Table 2, 38\% of the European students associate salt with foods; $35.1 \%$ associate its structure and features; $15.9 \%$ associated it with human health and $11.1 \%$ associated it with areas of usage while identifying salt. An examination of the definitions reveals that the students do not take much interest in the usage areas of salt other than foods; and it was stated by the students that they did not give much importance to the effects of salt on human health. 
The distributions of the first four definitions on the concept of salt given by the students by countries basis is given in Table 3 .

Table 3

The distribution of the first four views of students regarding the question "What is salt?"

\begin{tabular}{|c|c|c|c|c|}
\hline $\begin{array}{l}\text { Rank } \\
\text { Country }\end{array}$ & First View & Second View & Third View & Fourth View \\
\hline TR & $\begin{array}{l}\text { The salt used in } \\
\text { cooking }\end{array}$ & $\begin{array}{l}\text { It is bad for your } \\
\text { health }\end{array}$ & $\begin{array}{l}\text { We find salt in } \\
\text { oceans and seas }\end{array}$ & $\begin{array}{l}\text { Salt is made from } \\
\text { small crystals and } \\
\text { white }\end{array}$ \\
\hline GR & We put it on food & $\begin{array}{l}\text { We find salt in } \\
\text { oceans and seas }\end{array}$ & Salt is in the body & $\begin{array}{l}\text { The salt used in } \\
\text { cooking }\end{array}$ \\
\hline $\mathrm{D}$ & $\begin{array}{l}\text { The salt used in } \\
\text { cooking }\end{array}$ & $\begin{array}{l}\text { Salt is poison for } \\
\text { snails and slugs }\end{array}$ & Salt is in the body & $\begin{array}{l}\text { Salt is made from } \\
\text { small crystals and } \\
\text { white }\end{array}$ \\
\hline $\mathrm{SCO}$ & We put it on food & $\begin{array}{l}\text { We find salt in } \\
\text { oceans and seas }\end{array}$ & $\begin{array}{l}\text { The salt used in } \\
\text { cooking }\end{array}$ & It is a mineral \\
\hline $\mathrm{E}$ & $\begin{array}{l}\text { The salt used in } \\
\text { cooking }\end{array}$ & $\begin{array}{l}\text { We find salt in } \\
\text { oceans and seas }\end{array}$ & $\begin{array}{l}\text { Salt make you are } \\
\text { thristy }\end{array}$ & $\begin{array}{l}\text { It is bad for your } \\
\text { health }\end{array}$ \\
\hline PL & $\begin{array}{l}\text { Salt is made from } \\
\text { small crystals and } \\
\text { white }\end{array}$ & Salt is a spice & $\begin{array}{l}\text { It is bad for your } \\
\text { health }\end{array}$ & $\begin{array}{l}\text { We find salt in } \\
\text { oceans and seas }\end{array}$ \\
\hline $\mathrm{RO}$ & $\begin{array}{l}\text { The salt used in } \\
\text { cooking }\end{array}$ & It is a mineral & It melts the ice & $\begin{array}{l}\text { Salt is made from } \\
\text { small crystals and } \\
\text { white }\end{array}$ \\
\hline EST & It melts the ice & $\begin{array}{l}\text { The salt used in } \\
\text { cooking }\end{array}$ & $\begin{array}{l}\text { Salt is made from } \\
\text { small crystals and } \\
\text { white }\end{array}$ & Salt is a spice \\
\hline I & $\begin{array}{l}\text { We find salt in } \\
\text { oceans and seas }\end{array}$ & It is a mineral & $\begin{array}{l}\text { It is bad for your } \\
\text { health }\end{array}$ & $\begin{array}{l}\text { Salt is good for } \\
\text { beauty }\end{array}$ \\
\hline A & rock salt & $\begin{array}{l}\text { We find salt in } \\
\text { oceans and seas }\end{array}$ & & \\
\hline
\end{tabular}

Definition related to food: -The salt used in cooking, -We put it on food, -Salt is a spice; ${ }^{2}$ Definition related to structure: -We find salt in oceans and seas, -Salt is made from small crystals and white, -It is a mineral, -Salt has different colours and forms, -Rock salt; ${ }^{3}$ Definition related to health: -Salt is good for beauty, -It is bad for your health, -Salt is in the body, -Salt makes you thirsty; ${ }^{4}$ Definiton related to usage areas: -It melts the ice, -Salt is poison for snails and slugs, -Salt can kill plants

According to the results given in Table 3, when the numbers of definitions of salt given by students on countries basis are ordered from big to small, the ratios that were in the first four were definitions regarding the use of salt in foods ( 9 countries), definitions regarding the structure of salt ( 9 countries), definitions regarding the use of 
salt in healthcare (6 countries), and definitions on the harms of salt (3 countries). When the definitions given were checked, it was revealed that students did not take so much notice of the areas of usage of salt other than its use in foods and that they did not care for its effects on human health much.

\section{Student Views Regarding the Requirement Areas of Salt}

Distribution of students' views about the second open-ended question: "What do we need salt for? Tick off the answers you think are right" according to countries is given in Table 4.

Table 4

The percentage distributions of the views of students regarding the question "What do we need salt for?"

\begin{tabular}{|c|c|c|c|c|c|c|c|c|c|c|c|}
\hline $\begin{array}{l}\text { Country } \\
\text { Choices }\end{array}$ & $\mathrm{TR}$ & GR & $\mathrm{D}$ & $\mathrm{SCO}$ & $\mathrm{E}$ & PL & $\mathrm{RO}$ & EST & I & A & $\begin{array}{l}\text { Total } \\
(\%)\end{array}$ \\
\hline \multirow[t]{2}{*}{ Animals } & 1 & 1 & 2 & 3 & 0 & 6 & 5 & 7 & 1 & 4 & 30 \\
\hline & $2.9 \%$ & $1.6 \%$ & $5.4 \%$ & $6.4 \%$ & $0 \%$ & $11.3 \%$ & $8.3 \%$ & $13.7 \%$ & $2.3 \%$ & $21.1 \%$ & $6.7 \%$ \\
\hline \multirow{2}{*}{$\begin{array}{l}\text { Beauty } \\
\text { treatment }\end{array}$} & 1 & 8 & 4 & 6 & 3 & 2 & 1 & 3 & 3 & 1 & 32 \\
\hline & $2.9 \%$ & $12.5 \%$ & $10.8 \%$ & $12.8 \%$ & $8.1 \%$ & $3.8 \%$ & $1.7 \%$ & $5.9 \%$ & $6.8 \%$ & $5.3 \%$ & $7.2 \%$ \\
\hline \multirow[t]{2}{*}{ Car } & 0 & 0 & 0 & 0 & 1 & 4 & 0 & 0 & 0 & 2 & 7 \\
\hline & $0 \%$ & $0 \%$ & $0 \%$ & $0 \%$ & $2.7 \%$ & $7.5 \%$ & $0 \%$ & $0 \%$ & $0 \%$ & $10.5 \%$ & $1.6 \%$ \\
\hline \multirow[t]{2}{*}{ Cooking } & 15 & 17 & 11 & 15 & 20 & 15 & 20 & 20 & 20 & 2 & 155 \\
\hline & $44.1 \%$ & $26.6 \%$ & $29.7 \%$ & $31.9 \%$ & $54.1 \%$ & $28.3 \%$ & $33.3 \%$ & $39.2 \%$ & $45.5 \%$ & $10.5 \%$ & $34.8 \%$ \\
\hline \multirow[t]{2}{*}{ Gardening } & 1 & 4 & 0 & 4 & 0 & 4 & 11 & 2 & 6 & 1 & 33 \\
\hline & $2.9 \%$ & $6.3 \%$ & $0 \%$ & $8.5 \%$ & $0 \%$ & $7.5 \%$ & $18.3 \%$ & $3.9 \%$ & $13.6 \%$ & $5.3 \%$ & $7.4 \%$ \\
\hline \multirow[t]{2}{*}{ Health } & 8 & 14 & 9 & 7 & 3 & 5 & 13 & 7 & 0 & 4 & 70 \\
\hline & $23.5 \%$ & $21.9 \%$ & $24.3 \%$ & $14.9 \%$ & $8.1 \%$ & $9.4 \%$ & $21.7 \%$ & $13.7 \%$ & $0 \%$ & $21.1 \%$ & $15.7 \%$ \\
\hline \multirow[t]{2}{*}{ Medicine } & 6 & 9 & 5 & 9 & 7 & 9 & 8 & 6 & 9 & 2 & 70 \\
\hline & $17.6 \%$ & $14.1 \%$ & $13.5 \%$ & $19.1 \%$ & $18.9 \%$ & $17 \%$ & $13.3 \%$ & $11.8 \%$ & $20.5 \%$ & $10.5 \%$ & $15.7 \%$ \\
\hline \multirow[t]{2}{*}{ Playing } & 0 & 0 & 0 & 1 & 2 & 2 & 0 & 0 & 1 & 0 & 6 \\
\hline & $0 \%$ & $0 \%$ & $0 \%$ & $2.1 \%$ & $5.4 \%$ & $3.8 \%$ & $0 \%$ & $0 \%$ & $2.3 \%$ & $0 \%$ & $1.3 \%$ \\
\hline \multirow[t]{2}{*}{ Summer } & 2 & 4 & 1 & 0 & 0 & 0 & 1 & 0 & 1 & 0 & 9 \\
\hline & $5.9 \%$ & $6.3 \%$ & $2.7 \%$ & $0 \%$ & $0 \%$ & $0 \%$ & $1.7 \%$ & $0 \%$ & $2.3 \%$ & $0 \%$ & $2 \%$ \\
\hline \multirow[t]{2}{*}{ Washing } & 0 & 7 & 5 & 2 & 1 & 6 & 1 & 6 & 3 & 3 & 34 \\
\hline & $0 \%$ & $10.9 \%$ & $13.5 \%$ & $4.3 \%$ & $2.7 \%$ & $11.3 \%$ & $1.7 \%$ & $11.8 \%$ & $6.8 \%$ & $15.8 \%$ & $7.6 \%$ \\
\hline Total & 34 & 64 & 37 & 47 & 37 & 53 & 60 & 51 & 44 & 19 & 446 \\
\hline
\end{tabular}

According to the results given in Table 4, 34.8\% of European students defined salt as a nutrient that they required while cooking while $15.7 \%$ of them stated that they 
needed salt in terms of healthcare and medicine. The students were not aware of the requirement of salt in beauty treatment, automobiles, gardens, games, washing and sweating in the summer months.

The first four of the answer of students regarding the requirement areas of salt on countries basis are given in Table 5 .

Table 5

The distribution of the first four views of students regarding the question "What do we need salt for?"

\begin{tabular}{lllll}
\hline \multicolumn{1}{c}{ Rank } & First View & Second View & Third View & Fourth View \\
\hline TR & Cooking & Health & Medicine & --- \\
GR & Cooking & Health & Winter & Medicine \\
D & Cooking & Health & Medicine & Washing \\
SCO & Cooking & Medicine & Health & Winter \\
E & Cooking & Winter & Medicine & Health \\
PL & Cooking & Winter & Medicine & Washing \\
RO & Cooking & Health & Gardening & Medicine \\
EST & Cooking & Winter & Health & Animals \\
I & Cooking & Winter & Medicine & Gardening \\
A & Winter & Animals & Health & -- \\
\hline
\end{tabular}

When the preferences of students on salt are ordered from the biggest to the smallest, the ratios that were in the first four were the requirement for salt are for cooking (9 countries), the necessity of salt for healthcare and medicines (8 countries), and the necessity of use of salt during winter ( 7 countries).

For the questions "Do you think salt is necessary for: Tick off Yes or No or Don't know:", The students were asked to mark the ones that they did not consider necessary or did not know among the items "Food, Dogs, Living, ice skating, playing football, Water, Plants, Ocean, River, Ants, Dolphin, Health". The frequency and percentage distributions of those that said "yes, it is necessary", "no, it is not necessary" and did not know on countries basis are given in Table 6. 
Table 6

The percentage distributions of the views of students regarding the question "Do you think salt is necessary for : Tick off Yes or No or Don't know: "

\begin{tabular}{|c|c|c|c|c|c|c|c|c|c|c|c|c|}
\hline \multicolumn{13}{|c|}{ Country } \\
\hline & & TR & GR & $\mathrm{D}$ & SCO & $\mathrm{E}$ & PL & RO & $\mathrm{EST}$ & I & A & Total (\%) \\
\hline \multirow{10}{*}{ 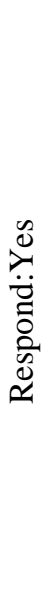 } & Food & 15 & 15 & 12 & 12 & 20 & 16 & 20 & 2 & 20 & 6 & 138 \\
\hline & & $23.1 \%$ & $19.7 \%$ & $27.3 \%$ & $23.1 \%$ & $34.5 \%$ & $23.2 \%$ & $25.3 \%$ & $3.6 \%$ & $29 \%$ & $15.4 \%$ & $22.7 \%$ \\
\hline & Ocean & 10 & 15 & 10 & 8 & 15 & 15 & 12 & 11 & 15 & 5 & 116 \\
\hline & & $15.4 \%$ & $19.7 \%$ & $22.7 \%$ & $15.4 \%$ & $25.9 \%$ & $21.7 \%$ & $15.2 \%$ & $19.6 \%$ & $21.7 \%$ & $12.8 \%$ & $19.1 \%$ \\
\hline & Health & 9 & 13 & 6 & 7 & 2 & 6 & 13 & 8 & 7 & 6 & 77 \\
\hline & & $13.8 \%$ & $17.1 \%$ & $13.6 \%$ & $13.5 \%$ & $3.4 \%$ & $8.7 \%$ & $16.5 \%$ & $14.3 \%$ & $10.1 \%$ & $15.4 \%$ & $12.7 \%$ \\
\hline & Living & 12 & 7 & 5 & 2 & 5 & 11 & 7 & 7 & 6 & 7 & 69 \\
\hline & & $18.5 \%$ & $9.2 \%$ & $11.4 \%$ & $3.8 \%$ & $8.6 \%$ & $15.9 \%$ & $8.9 \%$ & $12.5 \%$ & $8.7 \%$ & $17.9 \%$ & $11.4 \%$ \\
\hline & Total & 65 & 76 & 44 & 52 & 58 & 69 & 79 & 56 & 69 & 39 & 607 \\
\hline & & & & & & & & & & & & $100 \%$ \\
\hline \multirow{10}{*}{ 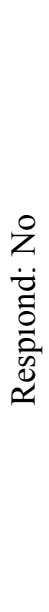 } & Playing & 10 & 14 & 10 & 11 & 20 & 11 & 19 & 13 & 18 & 6 & 132 \\
\hline & football & $21.7 \%$ & $16.5 \%$ & $15.6 \%$ & $12.6 \%$ & $13.9 \%$ & $16.9 \%$ & $17.3 \%$ & $11.2 \%$ & $16.2 \%$ & $19.4 \%$ & $15.4 \%$ \\
\hline & Dogs & 6 & 12 & 10 & 14 & 18 & 14 & 17 & 14 & 18 & 5 & 128 \\
\hline & & $13 \%$ & $14.1 \%$ & $15.6 \%$ & $16.1 \%$ & $12.5 \%$ & $21.5 \%$ & $15.5 \%$ & $12.1 \%$ & $16.2 \%$ & $16.1 \%$ & $14.9 \%$ \\
\hline & Ice & 8 & 6 & 10 & 9 & 16 & 9 & 19 & 12 & 12 & 3 & 104 \\
\hline & scating & $17.4 \%$ & $7.1 \%$ & $15.6 \%$ & $10.3 \%$ & $11.1 \%$ & $13.8 \%$ & $17.3 \%$ & $10.3 \%$ & $10.8 \%$ & $9.7 \%$ & $12.1 \%$ \\
\hline & Ants & 4 & 12 & 10 & 11 & 18 & 4 & 10 & 13 & 12 & 4 & 98 \\
\hline & & $8.7 \%$ & $14.1 \%$ & $15.6 \%$ & $12.6 \%$ & $12.5 \%$ & $6.2 \%$ & $9.1 \%$ & $11.2 \%$ & $10.8 \%$ & $12.9 \%$ & $11.4 \%$ \\
\hline & Total & 46 & 85 & 64 & 87 & 144 & 65 & 110 & 116 & 111 & 31 & 859 \\
\hline & & & & & & & & & & & & $100 \%$ \\
\hline \multirow{9}{*}{ 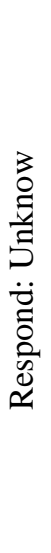 } & Water & 7 & 7 & 7 & 5 & 10 & 10 & 6 & 4 & 8 & 0 & 64 \\
\hline & & $10.3 \%$ & $14.6 \%$ & $15.9 \%$ & $13.2 \%$ & $26.3 \%$ & $14.7 \%$ & $12 \%$ & $9.1 \%$ & $13.3 \%$ & $0 \%$ & $13.6 \%$ \\
\hline & Dolphin & 11 & 7 & 6 & 5 & 1 & 8 & 5 & 7 & 6 & 2 & 58 \\
\hline & & $16.2 \%$ & $14.6 \%$ & $13.6 \%$ & $13.2 \%$ & $2.6 \%$ & $11.8 \%$ & $10 \%$ & $15.9 \%$ & $10 \%$ & $14.3 \%$ & $12.3 \%$ \\
\hline & Plants & 8 & 5 & 5 & 4 & 8 & 8 & 5 & 4 & 6 & 1 & 54 \\
\hline & & $11.8 \%$ & $10.4 \%$ & $11.4 \%$ & $10.5 \%$ & $21.1 \%$ & $11.8 \%$ & $10 \%$ & $9.1 \%$ & $10 \%$ & $7.1 \%$ & $11.4 \%$ \\
\hline & Ants & 8 & 5 & 3 & 4 & 2 & 12 & 4 & 6 & 6 & 3 & 53 \\
\hline & & $11.8 \%$ & $10.4 \%$ & $6.8 \%$ & $10.5 \%$ & $5.3 \%$ & $17.6 \%$ & $8 \%$ & $13.6 \%$ & $10 \%$ & $21.4 \%$ & $11.2 \%$ \\
\hline & Total & 68 & 48 & 44 & 38 & 38 & 68 & 50 & 44 & 60 & 14 & 472 \\
\hline
\end{tabular}


The distribution among countries of the first four of those that stated "yes, it is necessary", "no, it is not necessary" and did not know on countries basis is given in Table 7.

\section{Table 7}

The distribution of the first four views of the students on the question "Do you think salt is necessary for : Tick off Yes or No or Don't know"

\begin{tabular}{|c|c|c|c|c|c|c|c|c|c|c|c|}
\hline \multicolumn{2}{|c|}{$\begin{array}{l}\text { Country } \\
\text { Rank }\end{array}$} & $\mathrm{TR}$ & GR & $\mathrm{D}$ & SCO & E & PL & $\mathrm{RO}$ & EST & I & A \\
\hline \multirow{4}{*}{ 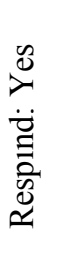 } & 1 & Food & Food & Food & Food & Food & Food & Food & Ocean & Food & Living \\
\hline & 2 & Living & Ocean & Ocean & Ocean & Ocean & Ocean & Health & Water & Ocean & Food \\
\hline & 3 & Ocean & Health & Health & Health & River & Living & Ocean & Health & Health & Health \\
\hline & 4 & Health & Plants & Living & River & Water & Health & Water & Living & Plants & Ocean \\
\hline \multirow{4}{*}{ 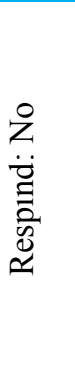 } & 1 & Football & River & Football & Dogs & Football & Dogs & Football & Dogs & Dogs & Football \\
\hline & 2 & $\begin{array}{l}\text { Ice } \\
\text { scating }\end{array}$ & Football & Dogs & Football & Dogs & Football & $\begin{array}{l}\text { Ice } \\
\text { scating }\end{array}$ & Football & Football & Dogs \\
\hline & 3 & Dogs & Dogs & Ants & Ants & Ants & River & Dogs & Ants & River & Dolphin \\
\hline & 4 & Water & Ants & $\begin{array}{l}\text { Ice } \\
\text { Scating }\end{array}$ & $\begin{array}{l}\text { Ice } \\
\text { scating }\end{array}$ & Dolphin & $\begin{array}{l}\text { Ice } \\
\text { scating }\end{array}$ & Dolphin & Plants & Ants & Ants \\
\hline \multirow{4}{*}{ 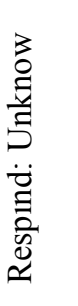 } & 1 & Dolphin & Do & Water & Water & Water & Ants & Living & Dolphin & Health & Ants \\
\hline & 2 & Plants & Water & Dolphin & Dolphin & Plants & Water & River & Health & Living & Dolphin \\
\hline & 3 & Ants & Dogs & Living & Ocean & Living & Health & Water & Ants & Water & $\begin{array}{l}\text { Ice } \\
\text { scating }\end{array}$ \\
\hline & 4 & Water & Living & Plants & Living & River & Plants & Health & Water & Dolphin & River \\
\hline
\end{tabular}

When the sequencing of those who answered "yes" and took part in the first four in Tables 6 and 7 are examined, it can be seen that the students considered salt necessary in the ocean (10 countries), in nutritions ( 9 countries), in healthcare ( 9 countries) and in life ( 5 countries). When the sequencing of those who answered "no" and took part in the list is examined, the students stated that salt was unnecessary for football (10 country), dogs (10 country), ants ( 7 countries) and ice skating (5 countries). The sequencing of those that answered "I don't know" showed that students had no knowledge regarding the necessity of salt in Water ( 9 countries), Dolphins ( 7 countries), Living (6 countries), Plants (4 countries), Ants (4 Countries), Health (4 countries). A general view showed that the students did not think that salt is necessary for all life forms; did not know the materials that are in the water and give hardness to it; wavered about the necessity of salt for health and did not have any clue about the importance of salt when combatting snow masses. 


\section{Student Views on Salt Recovery}

The students were asked to mark three of the items "ocean, mountains, shops, soil, plants, animals, mines, air" for the questions "Where do we find salt for production? Three ticks only!" the distribution among countries are given in Table 8 .

Table 8

The percentage distribution of the views of the students regarding the question "Where do we find salt for production? Three ticks only!"

\begin{tabular}{|c|c|c|c|c|c|c|c|c|c|c|c|}
\hline $\begin{array}{l}\text { Country } \\
\text { Choice }\end{array}$ & TR & GR & $\mathrm{D}$ & $\mathrm{SCO}$ & $\mathrm{E}$ & PL & RO & EST & I & A & $\begin{array}{l}\text { Total } \\
(\%)\end{array}$ \\
\hline \multirow[t]{2}{*}{ Animals } & 1 & 0 & 0 & 0 & 0 & 0 & 0 & 1 & 0 & 1 & 3 \\
\hline & $2.3 \%$ & $0 \%$ & $0 \%$ & $0 \%$ & $0 \%$ & $0 \%$ & $0 \%$ & $2 \%$ & $0 \%$ & $5.9 \%$ & $0.7 \%$ \\
\hline \multirow[t]{2}{*}{ Mines } & 13 & 12 & 2 & 14 & 11 & 14 & 16 & 10 & 14 & 0 & 106 \\
\hline & $30.2 \%$ & $26.1 \%$ & $5.9 \%$ & $31.1 \%$ & $18.6 \%$ & $27.5 \%$ & $27.6 \%$ & $20.4 \%$ & $32.6 \%$ & $0 \%$ & $23.8 \%$ \\
\hline \multirow[t]{2}{*}{ Plants } & 3 & 3 & 0 & 0 & 0 & 2 & 2 & 3 & 3 & 1 & 17 \\
\hline & $7 \%$ & $6.5 \%$ & $0 \%$ & $0 \%$ & $0 \%$ & $3.9 \%$ & $3.4 \%$ & $6.1 \%$ & $7 \%$ & $5.9 \%$ & $3.8 \%$ \\
\hline \multirow[t]{2}{*}{ Air } & 1 & 0 & 2 & 0 & 0 & 0 & 1 & 0 & 0 & 0 & 4 \\
\hline & $2.3 \%$ & $0 \%$ & $5.9 \%$ & $0 \%$ & $0 \%$ & $0 \%$ & $1.7 \%$ & $0 \%$ & $0 \%$ & $0 \%$ & $0.9 \%$ \\
\hline \multirow[t]{2}{*}{ Mountains } & 9 & 6 & 11 & 6 & 4 & 10 & 14 & 0 & 5 & 5 & 70 \\
\hline & $20.9 \%$ & $13 \%$ & $32.4 \%$ & $13.3 \%$ & $6.8 \%$ & $19.6 \%$ & $24.1 \%$ & $0 \%$ & $11.6 \%$ & $29.4 \%$ & $15.7 \%$ \\
\hline \multirow[t]{2}{*}{ Ocean } & 14 & 19 & 9 & 14 & 20 & 10 & 8 & 15 & 20 & 6 & 135 \\
\hline & $32.6 \%$ & $41.3 \%$ & $26.5 \%$ & $31.1 \%$ & $33.9 \%$ & $19.6 \%$ & $13.8 \%$ & $30.6 \%$ & $46.5 \%$ & $35.3 \%$ & $30.3 \%$ \\
\hline \multirow[t]{2}{*}{ Shops } & 1 & 4 & 8 & 10 & 18 & 9 & 15 & 14 & 1 & 2 & 82 \\
\hline & $2.3 \%$ & $8.7 \%$ & $23.5 \%$ & $22.2 \%$ & $30.5 \%$ & $17.6 \%$ & $25.9 \%$ & $28.6 \%$ & $2.3 \%$ & $11.8 \%$ & $18.4 \%$ \\
\hline \multirow[t]{2}{*}{ Soil } & 1 & 2 & 2 & 1 & 6 & 6 & 2 & 6 & 0 & 2 & 28 \\
\hline & $2.3 \%$ & $4.3 \%$ & $5.9 \%$ & $2.2 \%$ & $10.2 \%$ & $11.8 \%$ & $3.4 \%$ & $12.2 \%$ & $0 \%$ & $11.8 \%$ & $6.3 \%$ \\
\hline \multirow[t]{2}{*}{ Total } & 43 & 46 & 34 & 45 & 59 & 51 & 58 & 49 & 43 & 17 & 445 \\
\hline & & & & & & & & & & & $100 \%$ \\
\hline
\end{tabular}

According to the results in Table 8, the majority of European students think that salts are retrieved from the seas, mountains and mines, and shopping centers. A small minority of the students think that it can be extracted from plants and soil.

The first four of the views of students regarding the preferences of students of salt recovery on country basis is given in Table 9. 


\section{Table 9}

The distribution of the first four of the views of the students regarding the question

\begin{tabular}{|c|c|c|c|c|}
\hline Country $R$ Rank & First View & Second View & Third View & Fourth View \\
\hline TR & Ocean & Mines & Mountains & Plants \\
\hline GR & Ocean & Mines & Mountains & Shops \\
\hline $\mathrm{D}$ & Mountains & Ocean & Shops & Mines \\
\hline $\mathrm{SCO}$ & Ocean & Mines & Shops & Mountains \\
\hline E & Ocean & Shops & Mines & Soil \\
\hline PL & Mines & Ocean & Mountains & Shops \\
\hline RO & Mines & Shops & Mountains & Ocean \\
\hline EST & Ocean & Shops & Mines & Soil \\
\hline I & Ocean & Mines & Mountains & Plants \\
\hline A & Ocean & Mountains & Shops & Soil \\
\hline
\end{tabular}

According to the results in Table 9, when the first four sequencings of the preferences regarding the recovery of salt is examined, it is revealed that the great majority of European students think that salt is retrieved from seas (10 countries), mountains ( 8 countries) and mines ( 9 countries), shopping centers ( 8 countries), soil (3 countries) and plants (2 countries).

\section{Student Views on Salt Varieties Found in Daily Life}

The students were asked to mark the ones that they had seen of the salt varieties "fleur de sal, fleur de sel, fluorine salt, iodine salt, ocean salt, road salt, salt crystals, salt for the salt mill, salt from Hawaii, salt from the Himalaya, table salt" for the question "What kind of salt have you already seen ?" The country distribution of the first four choices in accordance with the sequencing on countries basis according to student answers is given in Table 10. 
Table 10

The percentage distribution of the views of students regarding the question "What kind of salt have you already seen ?"

\begin{tabular}{llllllllllll}
\hline Country & TR & GR & D & SCO & E & PL & RO & EST & I & A & $\begin{array}{l}\text { Total } \\
(\%)\end{array}$ \\
Choices & & & & & & & & & & & \\
Fleur de & 1 & 1 & 0 & 1 & 1 & 2 & 1 & 1 & 0 & 0 & 8 \\
sal & $2.7 \%$ & $1.3 \%$ & $0 \%$ & $1.8 \%$ & $1.7 \%$ & $3.7 \%$ & $1.5 \%$ & $2.1 \%$ & $0 \%$ & $0 \%$ & $1.4 \%$ \\
Fleur de & 0 & 1 & 0 & 0 & 2 & 0 & 1 & 0 & 4 & 0 & 8 \\
sel & $0 \%$ & $1.3 \%$ & $0 \%$ & $0 \%$ & $3.3 \%$ & $0 \%$ & $1.5 \%$ & $0 \%$ & $4.8 \%$ & $0 \%$ & $1.4 \%$ \\
Fluorine & 1 & 1 & 0 & 2 & 4 & 1 & 4 & 1 & 2 & 0 & 16 \\
salt & $2.7 \%$ & $1.3 \%$ & $0 \%$ & $3.6 \%$ & $6.7 \%$ & $1.9 \%$ & $5.9 \%$ & $2.1 \%$ & $2.4 \%$ & $0 \%$ & $2.9 \%$ \\
Iodine & 0 & 3 & 3 & 0 & 3 & 8 & 6 & 1 & 3 & 0 & 27 \\
salt & $0 \%$ & $3.8 \%$ & $6.4 \%$ & $0 \%$ & $5 \%$ & $14.8 \%$ & $8.8 \%$ & $2.1 \%$ & $3.6 \%$ & $0 \%$ & $4.9 \%$ \\
Ocean & 9 & 18 & 13 & 13 & 20 & 8 & 12 & 7 & 18 & 0 & 118 \\
salt & $24.3 \%$ & $22.5 \%$ & $27.7 \%$ & $23.6 \%$ & $33.3 \%$ & $14.8 \%$ & $17.6 \%$ & $14.9 \%$ & $21.7 \%$ & $0 \%$ & $21.3 \%$ \\
Road salt & 0 & 11 & 8 & 12 & 0 & 8 & 15 & 6 & 16 & 7 & 83 \\
& $0 \%$ & $13.8 \%$ & $17 \%$ & $21.8 \%$ & $0 \%$ & $14.8 \%$ & $22.1 \%$ & $12.8 \%$ & $19.3 \%$ & $31.8 \%$ & $15 \%$ \\
Salt & 9 & 9 & 9 & 10 & 10 & 12 & 6 & 6 & 10 & 6 & 87 \\
crystals & $24.3 \%$ & $11.3 \%$ & $19.1 \%$ & $18.2 \%$ & $16.7 \%$ & $22.2 \%$ & $8.8 \%$ & $12.8 \%$ & $12 \%$ & $27.3 \%$ & $15.7 \%$ \\
Salt mill & 0 & 12 & 0 & 3 & 8 & 2 & 8 & 3 & 10 & 8 & 54 \\
& $0 \%$ & $15 \%$ & $0 \%$ & $5.5 \%$ & $13.3 \%$ & $3.7 \%$ & $11.8 \%$ & $6.4 \%$ & $12 \%$ & $36.4 \%$ & $9.8 \%$ \\
Hawaii & 0 & 3 & 0 & 1 & 3 & 0 & 0 & 2 & 1 & 0 & 10 \\
salt & $0 \%$ & $3.8 \%$ & $0 \%$ & $1.8 \%$ & $5 \%$ & $0 \%$ & $0 \%$ & $4.3 \%$ & $1.2 \%$ & $0 \%$ & $1.8 \%$ \\
Himalaya & 2 & 3 & 8 & 0 & 4 & 2 & 1 & 1 & 4 & 1 & 26 \\
salt & $5.4 \%$ & $3.8 \%$ & $17 \%$ & $0 \%$ & $6.7 \%$ & $3.7 \%$ & $1.5 \%$ & $2.1 \%$ & $4.8 \%$ & $4.5 \%$ & $4.7 \%$ \\
Table & 15 & 18 & 6 & 13 & 5 & 11 & 14 & 19 & 15 & 0 & 116 \\
salt & $40.5 \%$ & $22.5 \%$ & $12.8 \%$ & $23.6 \%$ & $8.3 \%$ & $20.4 \%$ & $20.6 \%$ & $40.4 \%$ & $18.1 \%$ & $0 \%$ & $21 \%$ \\
Total & 37 & 80 & 47 & 55 & 60 & 54 & 68 & 47 & 83 & 22 & 553 \\
& & & & & & & & & & $100 \%$ \\
\hline
\end{tabular}

According to the results given in Table 10, the salt types that are mostly encountered by European students are marine salt by $21.3 \%$, chrystal salt by $15.7 \%$ and road salt by $15.0 \%$. The salt types that are least commonly known are iodine salt, Hawaii salt, flourine salt and Himalayan salt.

The distribution of the first four preferences of students regarding the salt types they have seen in their lives is given in Table 11. 


\section{Table 11}

The distribution of the first four of the views of students regarding the question "What kind of salt have you already seen ?"

\begin{tabular}{|c|c|c|c|c|}
\hline Rank & First View & Second View & Third View & Fourth View \\
\hline TR & Table salt & Ocean salt & Salt crystals & $\begin{array}{l}\text { Salt from the } \\
\text { Himalaya }\end{array}$ \\
\hline GR & Table salt & Ocean salt & Salt for the salt mill & Road salt \\
\hline $\mathrm{D}$ & Ocean salt & Salt crystals & Road salt & $\begin{array}{l}\text { Salt from the } \\
\text { Himalaya }\end{array}$ \\
\hline $\mathrm{SCO}$ & Ocean salt & Table salt & Road salt & Salt crystals \\
\hline $\mathrm{E}$ & Ocean salt & Salt crystals & Salt for the salt mill & Table salt \\
\hline PL & Salt crystals & Table salt & Ocean salt & Iodine salt \\
\hline RO & Road salt & Table salt & Ocean salt & Salt for the salt mill \\
\hline EST & Table salt & Ocean salt & Road salt & Salt crystals \\
\hline I & Ocean salt & Road salt & Table salt & Salt crystals \\
\hline A & Salt for the salt mill & Road salt & Salt crystals & $\begin{array}{l}\text { Salt from the } \\
\text { Himalaya }\end{array}$ \\
\hline
\end{tabular}

According to the results in Table 11, when the first four of the preferences regarding the types of salt they have seen in their lives is examined, a majority of the students in Europe have seen ocean salt ( 9 countries), table salt (8 countries), salt crystals ( 8 countries), road salt ( 7 countries) salt for the salt mill (4 countries), salt from the Himalayas ( 3 countries), iodine salt ( 1 country). By virtue of these results, it was revealed that the students have not seen fleur de sal, fleur de sel, flourine salt, salt crystals, salt for the salt mill, salt from Hawaii, salt from the Himalaya.

\section{Discussion and Conclusion}

Regarding students' definitions of salt, of the students from the participating countries; $38.0 \%$ associated salt with foods; $35.1 \%$ associated salt with buildings and features, $15.8 \%$ associated salt with human health and $11.1 \%$ associated salt with necessities and made their salt definitions accordingly. These definitions revealed that young people are not much interested in the uses of salt in areas other than nutritions and that they did not show much interest in its effects on human health. Similarly, when the answers by the students were evaluated under common themes and codes and the frequency figures were put into order from the biggest to the smallest, it can be seen that the results are similar. A close examination of the ratios show that the definitions of salt are superficial ones made based on solely the daily life examples. The ratios of identification of salt with regard to its structure and its effects on health are particularly low. A study by Marakis et al. (2013) in which a different measurement tool was used 
and adults were subjects reinforces the findings of this project research. The study was implemented on adults and the definition of salt was made generally based on foods. In this study, as can be seen in Table 2, the definition of salt was made based on foods with a percentage of 30-51, excluding Italy, Austria and Poland. In an online study supporting this study, Webster et al. (2010), 32.0\% of the participants stated that salt is bad for health while $14.0 \%$ determined the upper limit of salt consumption. These results reinforce the study by Webster et al. (2010). Grimes, Riddell and Nowson (2009) studied the knowledge and attitude of the participants on salt in a survey they carried out in Austria through the agency of a shopping center. According to the study, the percentage of the participants that are not aware of the presence of sodium in salt is 69 . The results attained from the project study are in compliance with these studies performed in Austria at different times. A statement relating to the presence of sodium in salt was not encountered in the findings of the project study. A research carried out by Sánchez et al. (2012) in Argentina, Costa Rica and Ecuador revealed that those people who do not know the definition of salt are not aware of what the sodium in salt is. The fact that there were no opinions on the presence of sodium in this study can be related to the fact that the number of the students defining salt was low. Kurt, Ekici and Aksu (2013) exhibited the mental model of biology teachers on the concept of salt and revealed that the participants based their definitions of salt generally on the examples they use in daily life. In this project study, as well, definitions were made with examples from daily life rather than detailed definitions. It can be said that the mental models about salt in daily life influence the definitions of the students. However, mental models that occur in daily life can bring about lack of information. Consequently, the lack of information in research results can be attributed to these models. Furthermore, examples and definitions of salt originated from the acid-base, base-metal and other ionic forms of salt were not encountered in the project research results. Considering the age of the participants, such definitions might not have been expected. Yet, at least examples of the salt form that results from acid-base could have been among the results.

Regarding their awareness of salt in terms of areas of necessity, between $12.7 \%$ and $22.7 \%$ of the students in participating countries emphasized that salt is necessary for nutrition, oceans, health and medicine. Moreover, $11.4 \%$ to $15.4 \%$ of the students stated that it is not necessary for football, dogs, ice skating and ants. In the same way, it can be said that students are unable to craft a concept of salt in their minds and define its place in daily life implicitly. Furthermore, the students did not show awareness on the necessity of salt for living things. They were unable to understand the necessity of salt for dogs, ants, dolphins and plants. The fact that the rates for the necessity of salt was low for foods, oceans and health shows that students did not comprehend the importance of salt in these areas. The idea that salt is not necessary for football may be associated with the misconception 'salt leads to oversweating". Similarly, a link between the low ratio of necessity of salt while cooking and "salt is found in all nutritions" can be made (Taber, 2002). The fact that sweating occurs while playing football, wandering in hot summer days and the sweat leaves white traces on clothes might have been the reason for this misconception. That foods like bacon, cheese and 
olives are salted might have led to a misconception among students that all foods must be salted. Salt takes part in osmosis-defussion topics in biology, solubility and acidbase-neutralization concepts in chemistry and electrolyse topic in physics. That the subject is dealt with in three different disciplines in different ways might result in a terminology problem relating to salt. Sánchez et al. (2012) showed the fact that there is not a common terminology as the reason of not comprehending the concept of salt and emphasized that a terminology should be created. The terms that are present in the teaching of salt should be reduced to a level that students can understand.

According to the views related with awareness of students in terms of recovery of salt, agreat majority of the students that participated in the study think that salt is extracted from seas $(30.3 \%)$, mines $(15.7 \%)$, mountains $(23.8 \%)$ and shopping centers (18.4\%). Few of the students know that salt can be obtained from plants and soil. On the country basis, when the selections of the students were put in order from the biggest to smallest and the first four views were evaluated, it was found out that a great majority of the students believe that salt is extracted from seas (10 countries), mines (9 countries), mountains ( 8 countries) and shopping centers ( 8 countries), soil ( 3 countries) and plants ( 2 countries). It can be reported that students do not have full information about how salt is produced. It was revealed that they had no information about the areas of usage of salt in plants and soil. Even though they know that fertilizers are used in agriculture, they are not aware of the fact that fertilizers are salt types. When plants burn, the ashes they leave behind is a mixture of salt. Minerals that cycle in living things are actually ionic forms of salt. It can be argued that students cannot wholly place functions of salt in biology topics. Kurt, Ekici and Aksu (2013) revealed that biology teacher candidates have cognitive incomptences and misconceptions regarding salt. The fact that the inadequacy of teachers in the concept of salt in plants and living things may show that it is normal at elementary education level. The functions of salt should definitelty be involved in education.

According to the views related with awareness of students in terms of the types of salt encountered in daily life, the salt types that the students that took part in the project have seen most are marine salt (21.3\%), table salt (21.0\%), crystal salt (15.7\%) and road salt $(15.0 \%)$. When the answers of the students regarding the recovery of salt are put in order from the biggest to the smallest on countries basis and the first four views are evaluated, it can be seen that a great majority of studetns have encountered ocean salt ( 9 countries), table salt (8 countries), salt crystals (8 countries), road salt ( 7 countries), salt for the salt mill (4 countries), salt from the Himalayas (3 countries), iodine salt (1 country). These results account for the fact that students have not encountered fleur de sal, fleur de sel, flourine salt, salt crystals, salt fort he salt mill, salt from Hawaii, salt from the Himalayas.

A general evaluation of the results of the project research and the definitions put forward that students do not take much notice of salt excluding its use in foods and that they do not have much knowledge of its effects on human health. Acquisitions in terms of the use of salt in areas other than nutritions can be compiled and given as sample 
activities in science courses. The fact that salt is essential for human body should be stressed out in subjects like geography and science and what kind of salt human body needs, where and how much should be stated. The necessity of salt in ice skating and other sports can be given in elementary courses via associations with daily lives. The damage loss of salt might lead to should be explained in courses like science and physical education. Salt samples from drinking water and running water should be compared in science lessons. The necessity of salt for plants should be emphasized; plants and the types of salt they need should be exemplified. To exemplify, fertilizers in agriculture are known, yet, not as salt. The toxic effects of salt on the living things that live on land can be taught in science courses. The harms of excessive salt on human body should also be stated in science and biology lessons. In science and chemistry lessons, how salt is obtained and its place on our tables and in our daily lives should be explained. The types of salt should be taught with examples in science and chemistry courses. In this project research, a measuerment tool consisting of open ended questions was used. The fact that the data obtained from this study is generalisible might be turned into an extensive attitude scale consisting of qualified options in terms of understanding the urgent action plans devoted to the reduction of salt consumption and the monitoring of social salt problem. An inter-disciplinary approach should be used for a common definition of the concept of salt and this definiton should be stressed out in course programs. 


\title{
TUZ (BÍLİM-SANAT-DİL-TEKNOLOJİ) Comenius Projesi: İlköğretim Öğrencilerinin Tuza Yönelik Görüşleri *
}

\author{
Ursula ONDRATSCHEK ${ }^{* *}$ \\ Ali Günay BALIM *** \\ Suat TURKOGUZ ${ }^{* * * *}$
}

Makale Gönderme Tarihi: 04 Kasım 2013

Makale Kabul Tarihi: 28 Mayıs 2014

ÖZET: Çalışmada, ilköğretim öğrencilerinin tuz yapısı, özellikleri ve kullanım alanlarına yönelik görüşlerinin incelenmesi amaçlanmıştır. Bu nedenle 2012 yılında Türkiye, Almanya, İtalya, Polonya, Yunanistan; İspanya, Estonya, Avusturya, Romanya, İskoçya'nın yer aldığ1 10 Avrupa ülkesinin ortak yürüttüğü "The SALT Comenius Project" kapsamında etkinlikler başlatılmıştır. Bu çalışmada yer alan projenin amacı, öğrencileri bilim, sanat, dil, teknoloji ve kültür bakımından birbirlerine kaynaştırmak ve toprakta yer alan, günlük yaşamlarında kullandıkları tuz hakkında algı ve farkındalık oluşturmaktır. İlk proje toplantısında öğrencilerin tuzun yapısı, özellikleri ve kullanım alanlarına yönelik görüşleri almak için yarı yapılandırılmış anket kullanılmıştır. Araştırmaya 10 Avrupa ülkesinden 161 ilköğretim öğrencisi katılmıştır. Araştırmada veriler nitel araştırma yöntemiyle toplanmıştır Araştırmanın sonucunda, Öğrencilerin çoğunluğu tuzun yemeklerde kullanılan bir madde olduğunu, tuzun sadece denizlerden elde edilebileceğini, tuzun küçük kristallerden oluştuğunu, sağlık için kötü olduğunu, sadece tuzun kaya tuzun'dan elde edilebileceğini inanmaktadırlar.

Anahtar sözcükler: : tuza yönelik görüşler, ilköğretim öğrencileri.

\section{Geniş Özet}

Amaç ve Önem: Tarih boyunca tuzun değişik konumlarından dolayı eskiden değeri paha biçilemez bir maddeyken günümüzde değerinin çok düşmesi hali hazırda bu maddenin öneminin olmadığının bir göstergesi değildir. Tuz, herhangi bir maddeye yüklenilen, maddi ve manevi değerlerin zaman için nasıl şekillenip değiştiğini anlama açısından önemli bir ders konusudur (Gölbaş ve Başıüyük, 2012). Bu kapsamda halk sağlığının korunması ve hastalıkların oluşumunun önlenmesi için ülkemizde de tuz tüketimine yönelik çeşitli çalışmalar yapılmaktadır (Çom, Irmak, Kesici ve Ilgaz, 2011). $\mathrm{Bu}$ kapsamda yapılan Avrupa Birliği Comenius projesi çalışmasında ilkokul öğrencilerinin tuz hakkındaki davranışlarının ortaya konması ve projeye dahil olan diğer avrupa ülkelerinde eğitim gören ilkokul öğrencileriyle davranışlarının karşılaştırılması ve eğitim açısından önerilerin getirilmesi amaçlanmıştır.

Yöntem: Araştırma, nitel araştırma yöntemlerinden tarama türü bir çalışmayla gerçekleştirilmiştir. Araştırmada veriler "THE SALT (SCIENCE-ARTS-LANGUAGETECHNOLOGY) COMENIUS PROJECT" adlı projeye katılan 10 Avrupa ülkesinde eğitim gören öğrencilere yöneltilen yarı-yapılandırılmış açık uçlu sorular ile toplanmış ve bu sorulardan elde edilen dokümanlar incelenerek analiz edilmiştir.

\footnotetext{
* Bu makale Polonya Krakow'da "World Conference on New Trends in Science Education (WCNTSE-2013)" adl1 sempozyumda sunulmuştur.

** Salt Comenius Proje Koordinatörü, Grundschule im Beerwinkel, Berlin, Almanya, ullaon@ penticom.de

**** Doç.Dr., Dokuz Eylül Universitesi, İzmir, agbalim@gmail.com

***** Sorumlu Yazar: Yrd.Doç.Dr., Dokuz Eylül Universitesi, İzmir, suat.turkoguz@ gmail.com
} 
Araştırma, 2012 y1lı içerisinde The Salt (Science-Arts-Language-Technology) Comenius Project kapsamındaki toplantılarda Türkiye, Almanya, Polonya, Romanya, Yunanistan, Estonya, İspanya, İtalya, Avusturya ve İskoçya'dan 6., 7. ve 8. sınıf 161 ilkokul öğrencisiyle gerçekleştirilmiştir.

Veri toplama aracı olarak açık uçlu beş sorudan oluşan yarı-yapılandırılmış bir form kullanılmıştır. Bu form, "Tuz nedir? Tuz hakkında bildiğiniz üç şey yazınız?", "Tuza neden ihtiyaç duyarız?" , "Tuza nerelerde ihtiyaç duyulur?" , "Tuz nasıl ve nerelerde üretilir?" , "Hayatında gördüğün tuz çeşitleri nelerdir?" sorularından oluşmaktadır.

Veriler, The Salt (Science-Arts-Language-Technology) Comenius Project kapsamındaki sırayla katılımcı Türkiye, Almanya, Polonya, Romanya, Yunanistan, Estonya, İspanya, İtalya, Avusturya ve İskoçya'daki ülkelerde öğrencilere formun dağıtılarak doldurması istenmesi vasıtasıyla toplanmıştır.

Verilerin analizinde "İçerik Analiz tekniği" kullanılmıştır. Araştırmanın güvenirliği, Güvenirlik = Görüş Birliği / Görüş Birliği + Görüş Ayrılığı x 100 formülü kullanılarak (Miles \& Huberman, 1994) hesaplanmıştır. Buna göre, üç araştırmacının yapmış olduğu kodlamalar arasındaki tutarlılık \%80 olarak belirlenmiştir.

Bulgular: Projede yer alan 10 avrupa ülkesindeki öğrencilere kendi dillerinde anlayacakları şekilde tuz ve kullanım alanları hakkında onların görüşlerini alan 5 maddeden oluşan açık-uçlu sorulardan oluşan bir görüş anketi dağıtılmıştır. Bu görüş anketinin içerik analizi sonucunda aşağıda soru maddeleriyle verilen bulgulara ulaşılmıştır.

"Tuz nedir? Tuz hakkında bildiğiniz üç şey yazınız?" birinci açık-uçlu sorusuna ilişkin sonuçlara göre ülkeler bazında öğrencilerin tuz hakkında yaptıkları tanım sayıları büyükten küçüğe sıralandığında ilk dörtte yer alan oranlar tuzun gıdaların içinde kullanımıyla ilgili tanım (9 Ülke), tuzun yapısı ile ilgili tanım (9 Ülke), Tuzun sağlıkta kullanımıyla ilgili tanım (6 Ülke) ve tuzun zararlı tanımı (3 Ülke) şeklinde olmuştur. Yapılan tanımlara bakıldığında öğrencilerin tuzun gıda dışında kullanım alanlarına fazla ilgi duymadıkları ve insan sağlığına etkilerine yönelik ilgilerinin çok fazla olmadığı ortaya çıkmştır.

"Tuza neden ihtiyaç duyarız?" ikinci açık-uçlu sorusuna ilişkin sonuçlara göre ülkeler bazında öğrencilerin tuzun ihtiyaç duyulan alanlara göre tercih sayıları büyükten küçüğe sıralandığında ilk dörtte yer alan oranlar tuzun yemek pişirme sırasında gerekliği (9 Ülke), tuzun sağlık ve tıbbi ilaçlar için gerekliliği (8 Ülke) ve tuzun kışın kullanımı için gerekliliği (7 Ülke) şeklinde olmuştur.

"Tuza nerelerde ihtiyaç duyulur?" üçüncü sorusuna ilişkin sonuçlara ülkeler bazında öğrencilerin tuzun ihtiyaç duyulan alanlara göre tercih sayıları büyükten küçüğe sıralandığında ilk dörtte yer alan siralamalara baktığımızda öğrenciler okyanusda (10 Ülke), gıdalarda (9 Ülke), sağlikda (9 Ülke) ve yaşamda (5 Ülke) gerekli olduğu görülmüştür. Genel olarak baktığımızda öğrencilerin tuzun her canlı form için gerekli 
olduğunu düşünmemekte, sularda yer alan ve sertlik veren maddeleri bilmemekte, sağlık için gerekliliği konusunda tereddüt yaşamakta ve karla mücadelede tuzun önemini farketmemektedir.

"Tuz nasıl ve nerelerde üretilir?" dördüncü sorusuna ilişkin sonuçlara göre avrupadaki öğrencilerin büyük çoğunluğu tuzların denizlerden elde edildiğini, dağlardan ve madenlerden elde edildiğini, alışveriş merkezlerinin ürettiğini düşünmektedir. Öğrencilerin çok azı bitkilerden ve topraktan üretildiğini düşünmektedir.

"Hayatında gördüğün tuz çeşitleri nelerdir?" beşinci sorusuna ilişkin sonuçlara göre avrupadaki öğrencilerin en çok gördüğü tuz türleri $\% 26,87$ oranında florinli tuz, \%20,72'si masa tuzu, \%17,27'si kristal tuzudur. En az görülen tuz ise iyotlu tuz ile himalaya tuzudur.

Tartışma ve Sonuçlar: Tuzların ABD ve Avrupa'da kullanım alanları bakımından sıralandığında birinci sırada kimya sanayi sektörü, ikinci sırada buzlanmayla mücadele, üçüncü sırada gıda sektörü ve en son olarak azda olsa dördüncü sirada diğer sektörler yer almaktadır (Kostick, 2001; ESPA, 2003). Türkiye'de bu sıralama yapıldığında ilk sırayı gıda sektörü, ikinci sırayı sanayi sektörü, üçüncü sırayı buzlanma ile mücadeleyi ve son sırayı diğer sektörler yer almaktadır (DPT, 1995). Öğrecilere tuzun tanımı ile ilgili sorulan sorulardan elde edilen yanıtlar doğrultusunda Avrupa'daki öğrencilerin bu soruya verdikleri cevaplar gruplanıp sıralandıktan sonra birinci sırayı gıda, ikinci sırayı sağlık üçüncü sırayı diğer kullanım alanları yer almıştır. Tuzun Dünya'daki kullanım alanlarında yer alan sıralamayla öğrencilerin yanıtlarından çıkan sıralama arasındaki tutarsızlık öğrencilerin tuz hakkındakı farkındalıklarının olmadığının göstergesidir. Özellikle Türkiye, Polanya ve Avusturya'daki öğrencilerin tuzun sanayideki diğer kullanım alanlarına ilgili olmaması ilginç bir bulgudur. Seçken (2010) üniversite öğrencileri üzerinde yaptı̆̆ kullanım alanlarına yönelik bazı yanılgılara sahip olduklarını, tuzları sadece $\mathrm{NaCl}$ 'den ibaret olduğunu diğer metal tuzlarını bilmediklerini ifade etmiştir. Bu araştırmada öğrenciler tuza yönelik yaptıkları tanımlardan yaklaşık \%40'1 tuzların yapıları hakkında tanım yapmışlardır. Öğrencilerin geriye kalan \%60'lık kısmı tuzun gıda ve sağlık üzerindeki tanımlarına yönelmişlerdir. Seçken (2010)'in üniversite öğrencilerinde gördüğü kavram yanılgılarının kaynağının ilköğretim çoğundaki öğrencilerin tuza yönelik algılarındaki belirgin eksiklikler olması ve bu eksiklikleri gidermeye yönelik öğretim programlarının yürürlükte olmaması gösterilebilir. Parman (2002)'de yaptığı araştırmada tuzun farklı kültürler üzerindeki etkilerini ve tutumlarını araştırmıştır. Bu araştırmada mideye alınan tuz miktarının insanın yaşamış olduğu çevrenin kültürüyle ilişkili olduğu ortaya konmuştur. Öğrencilerin tuza yönelik yaptıkları tanım ve tuza olan gereksinime yönelik cevaplarından söz konusu Comenius projesine dahil olan 10 avrupa ülkesindeki tuzun gıda olarak tüketimine yönelik oranlarının da farklı olduğu görülmüştür. $\mathrm{Bu}$ araştırmadan çıkan sonuçlarla Parman (2002)'ın ilişkilendirmesini yaptığı sonucun paralel olması kültür farklılığının tuz tüketiminde etkisini bir kez daha göstermiş durumdadır. Aynı şekilde Van Der Veen ve ark. (1999) yaptığı araştırmada 
günlük tuz tüketiminde geleneksel tutumların etkili olduğunu gösterdiği araştırmasındaki sonucuyla bu çalışmanın ve diğer çalışmanın bulgularıda uyuşmaktadır. 


\section{References}

Asaria, P., Chisholm, M., Mathers, C., Ezzati, M., \& Beaglehole, R. (2007). Chronic disease prevention: Health effects and financial costs of strategies to reduce salt intake and control tobacco use. Lancet, 370, 2044-2053. DOI:10.1016/S01406736(07)61698-5

Avcı, S. (2003). Ekonomik coğrafya açısından önemli bir maden: tuz. Ístanbul Üniversitesi Coğrafya Dergisi, 11, 21-45.

Bloch, D. (1996). Salt as money. Retrieved from http://www.salt.org.il/econ.html,

Çom, S.; Irmak, H.; Kesici, C., \& Ilgaz, Ş. (2011). Türkiye aşırı tuz tüketiminin azaltılması programı. Ankara: Deniz Matbaacilık.

DPT (1995). 7. Beş yıllık kalkınma planı, madencilik özel ihtisas komisyonu, endüstriyel hammaddeler alt komisyonu, kimya sanayii hammaddeleri çalışma grubu raporu: bor mineralleri, trona, sodyum sülfat, stronsiyum mineralleri. tuz. Ankara: Devlet Planlama Teşkilatı Yayını.

ESPA (2003). European salt producers association. Retrieved from http: //www.eusalt.com.

Filbeck, D.A. (2002). An analysis of the effects of globalization on the restructuring of higher education in Thailand. (Unpublished doctoral dissertation). The Faculty of the Graduate School of the University of Texas, Austin.

Geray, H. (2006). Toplumsal araştirmalarda nicel ve nitel yöntemlere giriş. Ankara: Siyasal Kitapevi.

Gökçe, O. (2006). İçerik analizi kuramsal ve pratik bilgiler. Ankara: Siyasal Kitabevi.

Gölbaş, A \& Başıbüyük, Z. (2012). Anadolu kültür oluşumunda tuzun rolü. Journal of Life Sciences, 1(1), 45-54.

Grimes, C. A., Riddell, L. J., \& Nowson, C. A. (2009). Consumer knowledge and attitudes to salt intake and labelled salt information. Appetite, 53(2), 189-194. DOI:10.1016/j.appet.2009.06.007

Kibirige, I., Osodo, J., \& Tlala, K. M. (2014). The Effect of predict-observe-explain strategy on learners' misconceptions about dissolved salts. Mediterranean Journal of Social Sciences, 5(4), 300. DOI: 10.5901/mjss.2014.v5n4p300

Kostick, D.S. (2001). Salt. U.S. Geological surveys minerals yearbook-2001, United States.

Kurlansky, M. (2003). Tuz-insanliğin tuzlu tarihi (A. Çakıroğlu, Çev.). İstanbul: Aykırı Yayınc1lık.

Kurt, H., Ekici, G., \& Aksu, Ö. (2013). Tuz: biyoloji öğretmen adaylarinin zihinsel modelleri. Ĕgitim ve Öğretim Araştırmaları Dergisi, 2(4), 244-255. ISSN: 21469199.

Marakis, G., Tsigarida, E., Mila, S., \& Panagiotakos, D. B. (2013). Knowledge, attitudes and behaviour of Greek adults towards salt consumption: a Hellenic Food 
Authority project. Public health nutrition, 1-17. DOI: $10.1017 /$ S1368980013002255

Miles, M. B., \& Huberman, A. M. (1994). An Expanded sourcebook qualitative data analysis. United States of America: Sage Publications.

Parman,S. (2002). Lot's wife and the old salt: cross-cultural comparisons of attitudes toward salt in relation to diet. Cross-Cultural Research, 36, 123; DOI: $10.1177 / 1069397102036002002$.

Sánchez G., Peña L., Varea S., Mogrovejo P., Goetschel M.L., Montero-Campos M.A., Mejía R., \& Adriana Blanco-Metzler A.B. (2012). Conocimientos, percepciones y comportamientos relacionados con el consumo de sal, la salud y el etiquetado nutricional en Argentina, Costa Rica y Ecuador. Rev Panam Salud Publica, 32(4), 259-64.

Sarmugam, R., Worsley, A., \& Wang, W. (2013). An examination of the mediating role of salt knowledge and beliefs on the relationship between socio-demographic factors and discretionary salt use: a cross-sectional study. International journal of behavioral nutrition and physical activity, 10(1), 1-9. DOI:10.1186/1479-5868-1025.

Seçken, N. (2010). Identifying student's misconceptions about SALT. Procedia Social and Behavioral Sciences, 2, 234-245. DOI:10.1016/j.sbspro.2010.03.004

Taber, K. (Ed.) (2002). Chemical misconceptions: prevention, diagnosis and care. London: The Royal Scociety of Chemistry.

Van der Veen, J.E.; De Graaf, C.; Van Dis, S.J.; \& Van Staveren, W.A. (1999). Determinants of salt use in cooked meals in the Netherlands: attitudes and practices of food preparers. European Journal of Clinical Nutrition, 53(5), 388-94.

Wang, S.S. (2010, Jun 21). Study counts benefits of cutting salt. The Wall Street Journal. Retrieved from http://online.wsj.com/

Webster, J., Li, N., Dunford, E. K., Nowson, C. A., \& Neal, B. (2010). Consumer awareness and self-reported behaviours related to salt consumption in Australia. Asia Pacific journal of clinical nutrition, 19(4), 550-554.

Yıldırım, A. \& Şimşek, H. (2005). Sosyal bilimlerde nitel araştirma yöntemleri (5.baskl). Ankara: Seçkin Yayıncılık. 